\title{
THE RESULTS OF THORACOPLASTY IN THE TREATMENT OF PULMONARY TUBERCULOSIS
}

\author{
BY \\ J. H. GOUGH, D. BARLOW, T. HOLMES SELlORS, AND V. C. THOMPSON \\ From the London Chest Hospital
}

(RECEIVED FOR PUblication MARCh 8, 1957)

Since the advent of modern chemotherapy has made resection for pulmonary tuberculosis a relatively safe procedure, the thoracoplasty operation has been falling into disfavour. Nevertheless, we have been impressed by the safety and good results of this operation in practice, and it was felt that it would be of some interest to review in detail a large series of patients who had submitted to conventional thoracoplasty operations under modern conditions, and in whom a long-term follow-up had been made. It is worth noting that, since Sellors's publication on the results of thoracoplasty in 1947, there has been only one comprehensive paper on the subject in the British literature (Laird, 1953), though Price Thomas has given his figures in a modern textbook (Price Thomas, 1952a). Other results have been published in recent years by Hagn-Meincke (1950), Lees, Yang, Papoulakos, Alexander, and Larralde (1951), Ottosen, Popp, Beatty, and Buckingham (1951), Refsum (1951), Adie, Childress, Brezing, and Taylor (1952), Hughes, Lowry, and Polk (1953), O'Brien, Wilson, Armada, and Vindzberg (1953), Seip (1953), Forsee (1954), Baffes, Schlotterbeck, and De Camp (1954), and Douglass and Bosworth (1954).

In this series the case material has been analysed in considerable detail in order that the results obtained might form some basis for comparison with those of resection series. It should be pointed out that few, if any, of the published papers on resection results are really adequate for an accurate evaluation of resection operations to be made. Many give no information about the type and extent of disease operated on, and it is certain that the results are favourably weighted by the inclusion of many patients who had resections for "residual necrotic foci" at a time when it was not realized that the prognosis in these patients is excellent on chemotherapy alone. Furthermore, the minimum follow-up periods are short, usually no more than six months. It is hardly surprising that many surgeons have hesitated to abandon such a well-tried operation as thoracoplasty.

In order to give an accurate indication of the value of thoracoplasty in the treatment of pulmonary tuberculosis, the following requirements should be satisfied:

(1) The series should consist of a large number of patients, operated on consecutively by a standard procedure.

(2) The operations should be carried out under the best and most modern conditions.

(3) All the patients should be followed up for at least five years after operation, none being lost.

(4) Accurate and detailed information should be given about the pre-operative condition of the patients, particularly as regards type and extent of disease. Clearly the results are of no significance unless they are related to the type of case selected for operation.

(5) The terms used, such as "active" and " quiescent," should be precisely defined, otherwise they are meaningless.

(6) There should be a control series of patients exactly comparable with the operation cases and treated under the same conditions except that no operation is performed. A random method of allocating patients between the two groups should be used.

In practice it is clearly not possible to obtain an adequate control series of patients ; nor would this be ethically justifiable. But the operation can only be evaluated if an attempt is made to fulfil all the other requirements. Unfortunately, two of these are to some extent incompatible. Thus, if a follow-up period of five years is to be obtained, the operative technique and management used will already be outdated in some respects 
when the survey is made. In particular, antituberculosis chemotherapy was in its infancy when the operations in the present series were performed. Though this renders the treatment given obsolete by present-day standards, it is of interest to know what results could be obtained without effective chemotherapy.

It is believed that the present series approaches these ideal requirements as closely as is possible.

\section{Plan of the Investigation}

Two hundred and thirty-one consecutive patients who submitted to thoracoplasty operations at the Arlesey Branch of the London Chest Hospital between December 1, 1947, and December 31, 1949, were studied and followed up for six to eight years. Patients having post-resection thoracoplasties were excluded, as were four operated on for "unexpandable lung" following artificial pneumothorax, all of whom made satisfactory recoveries. The series includes seven patients who had empyemata in addition to active parenchymal disease.

The patients comprised two main groups: first, those seen in the out-patient department of the London Chest Hospital and admitted to Arlesey for treatment ; secondly, patients transferred from a sanatorium for surgery, usually returning to the sanatorium to complete their convalescence. As many patients as possible were followed up at the London Chest Hospital. Where patients were unable to attend owing to the travelling distance involved, the appropriate chest physician was asked to complete a questionnaire.

\section{Analysis of the Case Material}

In order to evaluate the results of any method of treatment, in this case thoracoplasty, it is essential to know exactly what sort of case was selected. In this series a careful analysis has been made of the factors which might influence prognosis.

Social Status.-The majority of the patients came from the working class in the East End of London. In many cases housing conditions were bad.

SEX INCIDENCE.-Of the 231 patients, 111 were males and 120 females.

Age Groups.-These are set out in Table I.

\section{EXTENT OF DISEASE}

Foster-Carter, Myers, Goddard, Young, and Benjamin (1952) have pointed out that, as a general
TABLE I

AGE DISTRIBUTION

\begin{tabular}{c|c}
\hline Age on Admission & No. of Patients \\
\hline Under 20 & 9 \\
$20-24$ & 39 \\
$25-29$ & 52 \\
$30-34$ & 47 \\
$35-39$ & 38 \\
$40-44$ & 21 \\
$45-49$ & 21 \\
$50-54$ & 4 \\
\hline Total & 231
\end{tabular}

The youngest patient in the series was aged 15, the oldest 52 .

rule, the expectation of survival in pulmonary tuberculosis varies inversely with the radiological in extent of the disease. It follows that in order to $\doteq$ assess the significance of the results of thoraco- 0 plasty one must analyse and record the radiological extent of the disease at the time of operation. Any $\infty$ investigation which does not record this is of little value.

In the present series 97 patients $(42 \%)$ had unilateral disease and 134 patients $(58 \%)$ had bilateral disease, as assessed by studying the pre-operative chest radiographs. A patient having only a small . area of calcified disease on one side was classifieg as having unilateral disease.

Foster-Carter's method of classification of the extent of disease, being the most precise, was uset in this series. His three classes are as follows:

Class I : Patients with not more than one zone $\overrightarrow{\overrightarrow{0}}$ of one lung involved.

Class II : Patients with either two or three zones involved; these may be unilateral or bilateral.

Class III : Patients having bilateral disease $\stackrel{\unrhd}{x}$ affecting four or more zones.

The zones are obtained by drawing horizontal lines across the chest radiograph (P.A. view) through the second and fourth costal cartilages, thus dividing each lung field into three zones.

Again, the presence of a small area of calcified $D$ disease in a zone was disregarded. Table II shows

TABLE II

EXTENT OF DISEASE

\begin{tabular}{|c|c|}
\hline $\begin{array}{c}\text { Extent } \\
\text { (Foster-Carter's } \\
\text { Classification) }\end{array}$ & No. of Patients \\
\hline $\begin{array}{cl}\text { Class I } \\
,, & \text { II } \\
, & \text { III }\end{array}$ & $\begin{array}{l}38(16 \%) * \\
121(53 \%) \\
72(31 \%)\end{array}$ \\
\hline Total & $231(100 \%)$ \\
\hline
\end{tabular}

*All percentages correct to two significant figures. 
that most of the patients in this series had extensive disease.

\section{Cavitation on Operation Side}

Of the patients who have no cavity at operation, at least eight had a cavity previously which closed as a result of medical treatment.

The figures in Table III can only be an approximation. Sellors (1947) has stated that the term "cavity" is a radiological convention, since it is clear that very small areas of excavation cannot be seen either on the chest radiograph or on tomography. Moreover, only $34 \%$ of the patients in this series had pre-operative tomographs. It is also well recognized that quite large cavities may be present at necropsy or in resection specimens, which cannot be seen even on rescrutinizing the pre-operative tomographs. In this series, only unequivocal ring shadows were taken to represent cavities. "Vacuolation" was considered to indicate bronchiectasis.

Table III shows that $84 \%$ of these patients had definite cavitation immediately before operation.

TABLE III

SIZE OF CAVITIES IMMEDIATELY BEFORE OPERATION

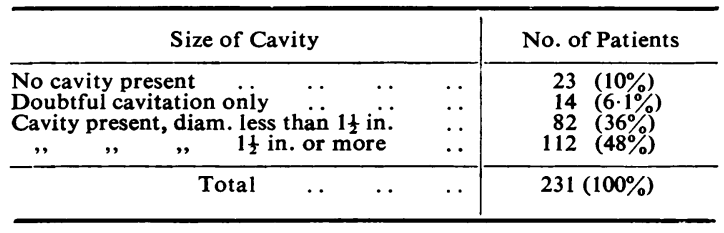

\section{BaCteriology of SPUTUM}

In only six cases was there no record that the patient had ever had a positive sputum. In all but a few cases a sputum specimen or gastric residue was cultured for tubercle bacilli during the preoperative six weeks. It will be seen from Table IV that many patients became sputum negative before operation as a result of treatment.

TABLE IV

SPUTUM STATE BEFORE OPERATION

\begin{tabular}{c|c}
\hline Sputum State & No. of Patients \\
\hline Positive sputum at some time before operation. . & 225 \\
No' positive' sputum within 6 weeks of operation. . & 171 \\
\end{tabular}

The details given above in regard to sex, age, extent of disease, cavitation, and bacteriology of sputum are sufficient to give a picture of the case material selected for operation. Figures relating to other factors such as site of cavity and the presence of a family history of tuberculosis are given in a later section.

\section{The Operations}

Chemotherapy was not given routinely to cover the operation period at the time when these operations were performed. This was in accordance with the recommendations in the report to the Medical Research Council (1951). Streptomycin or para-amino-salicylic acid (sometimes both) was given in $24 \%$ of the cases in this series, where there was some special indication for their use. A further $4 \%$ of patients had a course of chemotherapy at some time before operation. In view of the fact that the usual duration of chemotherapy was only six weeks, it is considered that chemotherapy had but slight effect on the results in this series.

The operations were standard staged paravertebral thoracoplasties with extrapleural apicolysis.

One hundred and twenty-two operations were performed on the left side, and 109 on the right side. Nine patients had a Monaldi drainage operation before starting the thoracoplasty.

TABLE V

EXTENT OF OPERATIONS

\begin{tabular}{|c|c|c|c|c|c|c|c|}
\hline Year & $\underset{\text { Ribs }}{1-4}$ & 5 Ribs & 6 Ribs & 7 Ribs & 8 Ribs & $\begin{array}{l}9 \text { or } \\
\text { More } \\
\text { Ribs }\end{array}$ & Total \\
\hline $\begin{array}{l}1947 \\
1948 \\
1949\end{array}$ & $\begin{array}{l}\overline{10} \\
10\end{array}$ & $\begin{array}{r}\overline{3} \\
\mathbf{3}\end{array}$ & $\begin{array}{l}\overline{16} \\
56\end{array}$ & $\begin{array}{l}\overline{27} \\
25\end{array}$ & $\begin{array}{r}4 \\
31 \\
33\end{array}$ & $\begin{array}{l}1 \\
7 \\
5\end{array}$ & $\begin{array}{r}5 \\
94 \\
132\end{array}$ \\
\hline Total & 20 & 6 & 72 & 52 & 68 & 13 & 231 \\
\hline
\end{tabular}

From Table V it can be seen that in 1949 the operation was becoming less radical as compared with 1948. This trend has continued since, and to-day it is rarely necessary to resect more than five or six ribs. In all but two of the patients having six-rib operations, the scapula was embedded by resecting the inferior angle. The scapula was embedded in all cases where seven or more ribs were resected.

In general the operations were performed under a local unless there was some good reason for giving a general anaesthetic.

Operation Mortality.-Three patients (1.3\%) died within three months of the last stage. Seip (1953) points out that the number of deaths within three months of operation is not an accurate indi- 
cation of the operation mortality, for a patient may die of a Semb space infection, for example, as long as a year later. In this series no other deaths could be attributed to the thoracoplasty operation.

All these three patients had extensive bilateral disease, involving all zones of the homolateral lung and at least two-thirds of the opposite lung. The first, a man aged 30 , died on the third day after the second stage ; the second, a man aged 37, died seven hours after the completion of an eight-rib thoracoplasty. Both these patients had a contralateral artificial pneumothorax and both died of respiratory insufficiency. The third patient, a woman aged 27 , collapsed and died suddenly as the local anaesthetic (amethocaine and adrenaline) was being injected before starting the second stage.

Post-operative Complications.-These occurred in 43 patients (19\%), but some were trivial. They usually occurred within six weeks of the last stage, but complications developing later were included when they were clearly related to the operation.

TABLE VI

POST-OPERATIVE COMPLICATIONS

\begin{tabular}{|c|c|c|c|}
\hline \multicolumn{3}{|l|}{ Complication } & No. of Patients \\
\hline $\begin{array}{l}\text { Atelectasis } \\
\text { Contralateral spread } \\
\text { reactivation } \\
\text { Homolateral spread } \\
\text { Extrapleural space infection (Staph } \\
\text { (tuber } \\
\text { Severe dyspnoea after" stages } \\
\text { Minor wound infections } \ldots \\
\text { Haematemesis } \\
\text { Severe exacerbation of gastric ulce } \\
\text { Haemorrhage into extrapleural spa } \\
\text { Air embolus (contralateral A.P.). } \\
\text { Intestinal obstruction (faecal impac } \\
\text { Paroxysmal auricular fibrillation . } \\
\text { Fracture of contralateral ist rib . }\end{array}$ & $\begin{array}{l}\cdots \\
\ldots \\
\ldots \\
\text { eus) } \\
\ldots \\
\ldots \\
\ldots \\
\ldots \\
\ldots \\
\ldots\end{array}$ & $\begin{array}{l}\ldots \\
\cdots \\
\cdots \\
\cdots \\
\cdots \\
\cdots \\
\cdots \\
\cdots \\
\cdots \\
\cdots \\
\cdots\end{array}$ & $\begin{array}{l}7 \\
9 \\
2 \\
5 \\
4 \\
4 \\
3 \\
2 \\
1 \\
1 \\
1 \\
1 \\
1 \\
1 \\
1\end{array}$ \\
\hline Total & $\ldots$ & $\ldots$ & 43 \\
\hline
\end{tabular}

Atelectasis.-The recorded incidence of atelectasis will depend on the frequency with which chest radiographs are obtained during the immediate post-operative period. In these patients chest films were usually obtained on the first, third, and sixth post-operative days, and then at longer intervals. In practice, it may be difficult to differentiate atelectasis from a post-operative pleural effusion.

Seven patients in this series developed atelectasis. In six the homolateral lower lobe was affected ; in the remaining patient the whole contralateral lung, which was already collapsed by an artificial pneumothorax, became atelectatic. Without ex- ception the collapsed lobe or lung re-expanded $\overrightarrow{\vec{F}}$ satisfactorily, bronchoscopy only being required in two.

TABLE VII

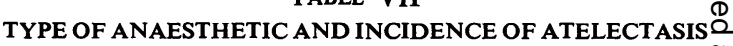

\begin{tabular}{|c|c|c|}
\hline $\begin{array}{c}\text { Type } \\
\text { of Anaesthetic }\end{array}$ & $\begin{array}{c}\text { Total } \\
\text { Patients }\end{array}$ & $\begin{array}{c}\text { Patients Developing } \\
\text { Atelectasis }\end{array}$ \\
\hline $\begin{array}{l}\text { General, all stages } \\
\text { Local, . } \\
\text { Both, at different stages . . }\end{array}$ & $\begin{array}{r}26 \\
177 \\
28 \\
\end{array}$ & $\begin{array}{c}1(3 \cdot 8 \%) \\
6(3 \cdot 4 \%) \\
-(-)\end{array}$ \\
\hline Total .. & 231 & $7(3.0 \%)$ \\
\hline
\end{tabular}

Table VII shows the incidence of atelectasis related to the type of anaesthetic, but the numbers $\rightarrow$ are too small for any significant conclusions to be윽 drawn. Laird (1953) considered that his figuressuggested that general anaesthesia carries a greater ${ }_{\mathbb{D}}^{\mathcal{D}}$ risk of post-operative atelectasis.

TABLE VIII

DIAPHRAGMATIC PARALYSIS AND INCIDENCE OF ATELECTASIS

\begin{tabular}{c|c|c|c|}
\hline $\begin{array}{c}\text { Function of } \\
\text { Diaphragm on } \\
\text { Operation } \\
\text { Side }\end{array}$ & $\begin{array}{c}\text { Total } \\
\text { Patients }\end{array}$ & $\begin{array}{c}\text { Patients } \\
\text { Developing } \\
\text { Atelectasis }\end{array}$ & $\begin{array}{c}\text { Patients Developing } \\
\text { Other Post-operation } \\
\text { Complications } \\
\text { Including Death }\end{array}$ \\
\hline $\begin{array}{c}\text { Paralysed } \\
\text { Not paralysed.. }\end{array}$ & 193 & $4(11 \%)$ & $6(16 \%)$ \\
\hline Total.. & 231 & $7(3.0 \%)$ & $33(17 \%)$ \\
\hline
\end{tabular}

* Includes one patient who developed an atelectatic lung under his contralateral A.P. (diaphragm not paralysed).

Though the number of patients in the series whơ developed atelectasis was small, Table VIII shows that the incidence of atelectasis was significantlyo higher in the group of patients who had a para $\frac{0}{x}$ lysed diaphragm on the operation side than in:those with a normally functioning diaphragm? This finding would be expected on theoretica grounds, for diaphragmatic paralysis impairs the efficiency of the cough mechanism to expel secre-o tion from the lower lobe bronchi on the affected side.

Haematemesis.-This occurred in one patien and another patient had a severe exacerbation of pain from a gastric ulcer which was known to be present previously.

Haematemesis is not uncommon in patients? undergoing thoracoplasty operations, and the authors have seen it in at least six othe patients besides the one in this series. It seems probable that the prolonged mental stress associ $\frac{0}{0}$ ated with this very painful and multiple-stage operation is responsible. 
Stress Fracture of Contralateral First Rib.-This is a recognized complication of thoracoplasty, cases having been reported by Guggenheim and Cohn (1948), Dingley (1950), and Rothstein and Gilboy (1952). It occurred in one patient in this series, being first visible in the chest radiograph 21 days after the third stage. Stress fractures of the first rib are not infrequent in healthy patients and often produce little or no pain so that they go unrecognized. Eley (1956) has found evidence of a previous fracture of the first rib in $0.7 \%$ of 10,000 mass miniature radiography films.

Evaluation of the Late Results

It was possible to follow all except three patients $(1.3 \%)$ to January 1 , 1956, giving a follow-up period of six to eight years after operation. These three patients were all discharged home after apparently successful operations with cavity closure and sputum conversion. They then changed their addresses and could not be traced.

Definitions.-To be classified as quiescent in this series the following criteria must be satisfied.
(1) The current chest radiograph must show no evidence of cavitation and there must be no recent radiological extension of disease.

(2) The patient must be abacillary ; that is, there must either be no sputum, or if present the sputum must be negative for tubercle bacilli by the methods used for examination. Cultures were obtained in about half the patients who had sputum, reliance being placed on the examination of smears in the remainder. Laryngeal swab cultures were obtained in only a small proportion of patients who could not produce any sputum.

TABLE IX

LATE FOLLOW-UP RESULTS (6-8 YEARS AFTER OPERATION)

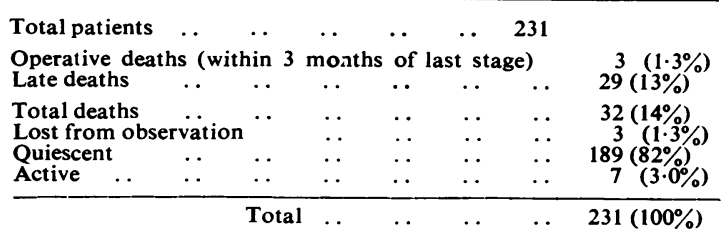

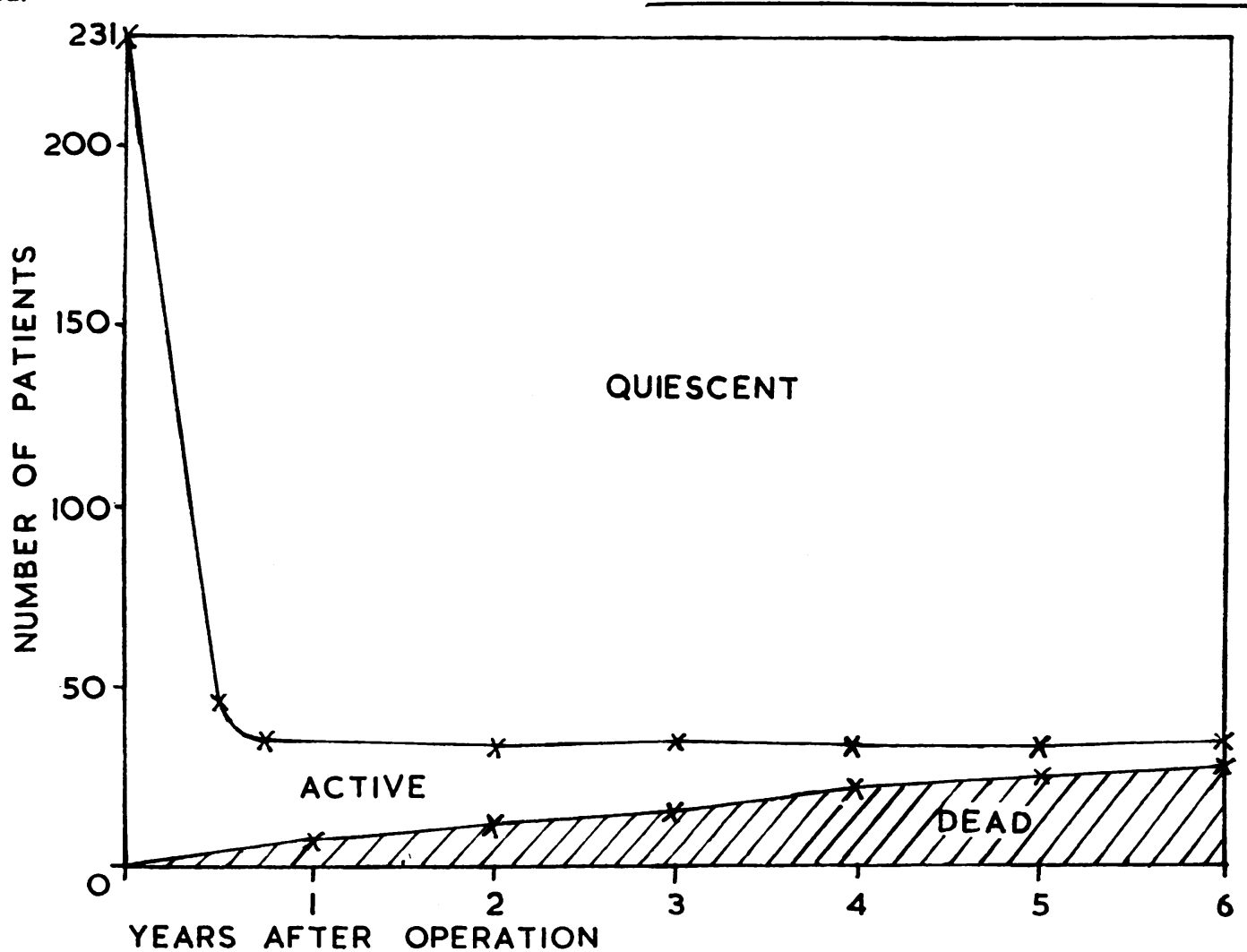

FIG. 1 
(3) The patient must not be undergoing treatment for tuberculosis other than out-patient supervision, and must not be a respiratory cripple.

All other surviving patients who did not fulfil the above criteria were regarded as active.

From Table IX it is seen that $82 \%$ of the total series of patients $(83 \%$ of those traced) are well and their disease quiescent at least six years after operation, whilst $14 \%$ have died and $3 \%$ still have active disease. These results can be regarded as satisfactory, for the operations were performed without the aid of effective chemotherapy, and, as already shown, a high proportion of the patients had extensive disease. The results of operations carried out at the present time would certainly show further improvement.

Fig. 1 gives a complete picture of the patients' disease status during the follow-up period. The number of those dead rises from year to year at a steady rate, whilst the number of patients who are quiescent rises rapidly at first, becoming almost constant after one year.

Table $X$ shows that $81 \%$ of the entire series of patients, or $96 \%$ of the survivors traced, are now fit for work ; with few exceptions they are working full-time. It must be realized, however, that many of them have been obliged to obtain light work owing to their respiratory disability. This percentage of patients fit for work is higher than any other in the thoracoplasty literature, and affords impressive testimony of the efficacy of the operation.

TABLE $X$ PRESENT WORK ABILITY OF PATIENTS

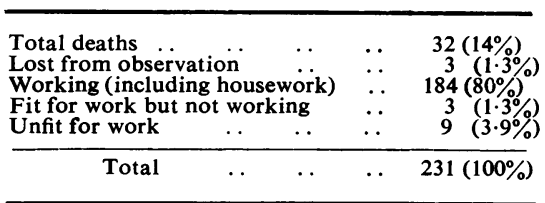

Late Deaths. - These numbered 29, excluding the three patients who died within three months of operation. It was possible to ascertain the cause of death in every case. In 26 cases death was partly or wholly due to pulmonary tuberculosis, and in three cases due to unrelated causes (one carcinoma of bronchus, one acute suppurative pneumonia, both confirmed by necropsy, one hypertensive heart failure associated with diabetes mellitus).

Table XI shows that four patients in the present series died of cor pulmonale. Both diffuse fibrosis
TABLE XI LATE DEATHS, PARTLY OR WHOLLY DUE TO PUL-

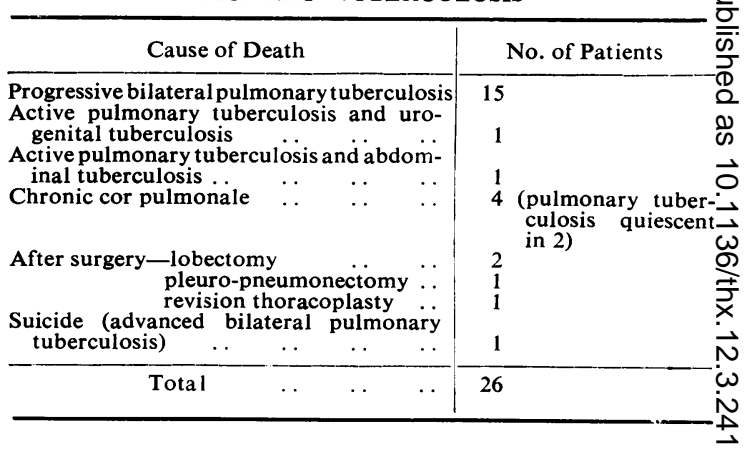

due to pulmonary tuberculosis and kyphoscoliosis은 are well-recognized causes of cor pulmonale, and since many thoracoplasty patients develop roto- $\mathbb{D}$ scoliosis it is only to be expected that some deaths from cor pulmonale will occur. All four patients had a history of chronic bronchitis with emphysema before surgery was embarked on.

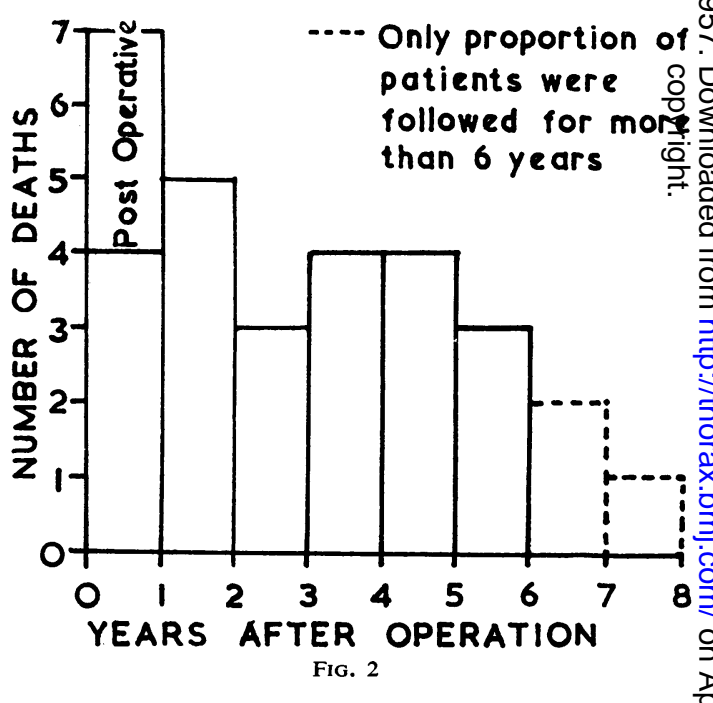

Fig. 2 shows that the number of deaths per year was remarkably constant during the six years of $N$ follow-up observation. It is therefore clear that $\mathrm{N}$ published operation results with a short follow-up period will be unduly optimistic.

Analysis of the Influence of Various Factors $\frac{0}{\mathbb{D}}$
ON LATE Prognosis

In a disease such as tuberculosis it is difficult to assess the effect of any single factor, because the $\frac{\text { ㅇ }}{\mathbb{P}}$ many different factors involved are interrelated. 
For example, if it is shown that patients with a family history of tuberculosis do worse than patients with no such family history, it cannot therefore be assumed that familial resistance to the disease is a significant factor influencing prognosis. It may be that the two groups are not comparable in regard to another factor which has an important influence on the prognosis. In the example given it is quite possible that the patients with a tuberculous family history have more extensive disease when diagnosed than the other group. Another difficulty is that it is not always possible to obtain large enough numbers in each sub-group under comparison to fulfil statistical criteria. Furthermore, other factors which are not analysable come into play such as social class, environment, temperament, and intelligence. For these reasons it is clear that great care must be taken in interpreting the results of the analysis.

In the study of factors which may influence prognosis the three patients who died from nontuberculous causes and three who were lost are excluded. Operative deaths are included.

TABLE XII

SEX AND PROGNOSIS

\begin{tabular}{c|c|c|c|c}
\hline \multirow{2}{*}{ Sex } & $\begin{array}{c}\text { Total } \\
\text { Patients }\end{array}$ & \multicolumn{3}{|c}{ Present Status } \\
\cline { 2 - 5 } & Quiescent & Active & Dead \\
\hline Males .. & 108 & $92(85 \%)$ & $3(2 \cdot 8 \%)$ & $13(12 \%)$ \\
Females . & 117 & $97(83 \%)$ & $4(3 \cdot 4 \%)$ & $16(14 \%)$ \\
\hline Total .. & 225 & $189(84 \%)$ & $7(3 \cdot 1 \%)$ & $29(13 \%)$ \\
\hline
\end{tabular}

It will be seen from Table XII that there is no significant difference in the late prognosis in the two sexes. Refsum (1951) reported similar findings.

TABLE XIII

AGE AND PROGNOSIS

\begin{tabular}{c|c|c|c|c}
\hline \multirow{2}{*}{ Age } & \multirow{2}{*}{$\begin{array}{c}\text { Total } \\
\text { Patients }\end{array}$} & \multicolumn{3}{|c}{ Present Status } \\
\cline { 4 - 5 } & & Quiescent & Active & Dead \\
\hline Under 20 & 9 & $8(89 \%)$ & - & $1(11 \%)$ \\
$20-24$ & 38 & $33(87 \%)$ & 1 & $4(11 \%)$ \\
$25-29$ & 50 & $46(92 \%)$ & 1 & $3(6 \%)$ \\
$30-34$ & 46 & $40(87 \%)$ & 1 & $5(11 \%)$ \\
$35-39$ & 38 & $30(79 \%)$ & 3 & $5(13 \%)$ \\
$40-44$ & 20 & $13(65 \%)$ & 1 & $6(30 \%)$ \\
$45-49$ & 20 & $16(80 \%)$ & - & $4(20 \%)$ \\
Over 50 & 4 & $3(75 \%)$ & - & $1(25 \%)$ \\
\hline Total .. & 225 & $189(84 \%)$ & $7(3.1 \%)$ & $29(13 \%)$ \\
\hline
\end{tabular}

As expected, Table XIII shows that the late prognosis is worse in the older age groups. Many of the older patients did well, and it is important that they should not be refused surgery on the score of age alone. Each case must be assessed individually. Price Thomas and Cleland wrote in 1942 that thoracoplasty was rarely indicated in patients over the age of 45 . More recently Beaconsfield, Coulthard, and Kergin (1954) and Pines and Rowlandson (1956) have studied series of thoracoplasty operations in patients over the age of 50, and shown that valuable results can be obtained if the cases are carefully selected. This conclusion is of importance because it is the elderly male patients who present the main problem in tuberculosis control at the present time.

ExTENT OF Disease.-In Table XIV the extent of disease at the time of operation is classified according to the method of Foster-Carter and his colleagues as described above.

TABLE XIV

EXTENT OF DISEASE AND PROGNOSIS

\begin{tabular}{c|c|c|c|c}
\hline $\begin{array}{c}\text { Extent of } \\
\text { Disease at Time } \\
\text { of Operation }\end{array}$ & $\begin{array}{c}\text { Total } \\
\text { Patie.ts }\end{array}$ & \multicolumn{3}{|c}{ Present Status } \\
\cline { 2 - 5 } & Quiescent & Active & Dead \\
\hline $\begin{array}{c}\text { Class I (1 zone) } \\
\text { Class II (2 or 3 } \\
\text { zones) }\end{array}$ & 36 & $36(100 \%)$ & Nil (0\%) & Nil (0\%) \\
$\begin{array}{c}\text { Class III (4 or } \\
\text { more zones) }\end{array}$ & 119 & $106(89 \%)$ & $5(4 \cdot 3 \%)$ & $8(6 \cdot 7 \%)$ \\
\hline Total & 70 & $47(67 \%)$ & $2(3.0 \%)$ & $21(30 \%)$ \\
\hline
\end{tabular}

Table XIV shows how survival is related to the extent of disease. Whilst every patient in Class I was quiescent at the end of the follow-up period, only $67 \%$ of Class III patients were quiescent and $30 \%$ were dead. Foster-Carter and his colleagues made a similar observation in their two series of patients treated conservatively and by collapse therapy. In each series the survival curve reflected closely the number of zones affected in the chest radiograph on admission. The prognosis was related to the extent of the disease, regardless of its nature, density, or the presence or absence of cavitation.

\section{TABLE XV}

PROGNOSIS IN UNILATERAL AND BILATERAL DISEASE

\begin{tabular}{cc|c|c|c|c}
\hline \multirow{2}{*}{$\begin{array}{c}\text { Extent of } \\
\text { Disease at Time } \\
\text { of Operation }\end{array}$} & $\begin{array}{c}\text { Total } \\
\text { Patients }\end{array}$ & \multicolumn{4}{|c}{ Present Status } \\
\cline { 3 - 6 } \begin{tabular}{cc|c|c|c} 
Qnilateral \\
Bilateral
\end{tabular} & $\cdots$ & 94 & $\begin{array}{c}89(95 \%) \\
\text { Buiescent }\end{array}$ & Active & Dead \\
\hline Total & $\cdots$ & 225 & $100(76 \%)$ & $5(3 \cdot 8 \%)$ & $\begin{array}{r}3(3 \cdot 2 \%) \\
26(20 \%)\end{array}$ \\
\hline
\end{tabular}

Table XV shows the marked difference between the prognosis in unilateral and bilateral cases. 
Pre-operative Sputum State.-In Table XVI a patient is considered to be positive if tubercle bacilli were found in one or more specimens of sputum or gastric residue within the six weeks before operation. In almost all cases cultures were obtained. The figures demonstrate clearly that the prognosis was much better in those patients who had converted their sputum before operation.

TABLE XVI

PRE-OPERATIVE SPUTUM STATE AND PROGNOSIS

\begin{tabular}{|c|c|c|c|c|}
\hline \multirow{2}{*}{ Sputum State } & \multirow{2}{*}{$\begin{array}{c}\text { Total } \\
\text { Patients }\end{array}$} & \multicolumn{3}{|c|}{ Present Status } \\
\hline & & Quiescent & Active & Dead \\
\hline $\begin{array}{c}\text { Sputum positive } \\
, \quad \text { negative }\end{array}$ & $\begin{array}{r}166 \\
59\end{array}$ & $\begin{array}{r}133(80 \%) \\
56(95 \%)\end{array}$ & $\begin{array}{l}5(3.0 \%) \\
2(3.4 \%)\end{array}$ & $\begin{array}{r}28(17 \%) \\
1(1.6 \%)\end{array}$ \\
\hline Total & 225 & $189(84 \%)$ & $7(3 \cdot 1 \%)$ & $29(13 \%)$ \\
\hline
\end{tabular}

Cavity Size on Operation Side.-In Table XVII the group of 14 patients with doubtful cavitation is too small for the figures to have

TABLE XVII

CAVITY SIZE AND PROGNOSIS

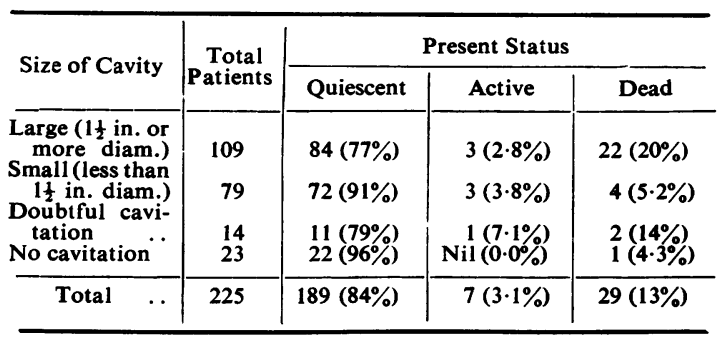

any significance. The table shows that there is a strong negative correlation between cavity size and survival.

Giant Cavities.-Twenty-three patients in the series had cavities measuring 3 in. or more in diameter. Of these, $16(70 \%)$ are now quiescent and seven $(30 \%)$ are dead. Seven of these patients had a Monaldi drainage operation before starting the thoracoplasty, and in each case this resulted in the cavity becoming smaller. Though giant cavities can be successfully closed by thoracoplasty operations, these must be extensive and much healthy tissue is compressed and ceases to function. Where possible it is preferable to treat patients with persistent giant cavities by resection, thus conserving more functioning lung tissue.

Site of Cavitation on Operation Side.-It is not always possible to determine with certainty in which segment, or even lobe, a cavity is situ- ated, even after studying postero-anterior and $\stackrel{\vec{\rho}}{\stackrel{\vec{S}}{+}}$ lateral radiographs, and antero-posterior and $\bar{C}$ lateral tomographs, for the inter-lobar fissures are not always visible and the pulmonary anatomy $\frac{\bar{\rho}}{\vec{D}}$ is often grossly distorted by fibrosis. The prob- $\triangle$ able site of cavitation was determined where possible.

TABLE XVIII

SITE OF CAVITATION

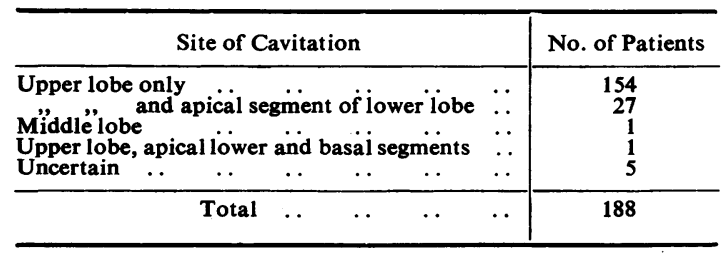

Table XVIII shows that all but one of the patients with cavities which could be localized had an upper lobe cavity. The sole exception was a patient who had a thoracoplasty after the rupture of a middle lobe cavity into the pneumothorax space.

Cavities in the Apical Segment of thig LOWER LOBE.-The operation result and subse quent fate of the 27 patients with apical lowe lobe cavities were studied, the patient with $a$ totally destroyed lung being excluded.

In one patient the operation was less extensive $\overrightarrow{\overrightarrow{0}}$ than planned. This patient had a contralateral spread after the first stage and died.

\section{TABLE XIX}

EXTENT OF ELECTIVE OPERATIONS AND PROGNOSIS IN PATIENTS WITH APICAL LOWER LOBE CAVITATION

\begin{tabular}{|c|c|c|c|c|c|}
\hline \multirow{2}{*}{\multicolumn{2}{|c|}{$\begin{array}{c}\text { Extent } \\
\text { of } \\
\text { Operation }\end{array}$}} & \multirow{2}{*}{$\begin{array}{c}\text { Total } \\
\text { Patients }\end{array}$} & \multicolumn{3}{|c|}{ Present Status } \\
\hline & & & Quiescent & Active & Dead \\
\hline 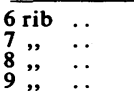 & $\begin{array}{l}\cdots \\
\cdots \\
\cdots\end{array}$ & $\begin{array}{r}5 \\
5 \\
13 \\
3\end{array}$ & $\begin{array}{l}\mathbf{2} \\
3 \\
8 \\
3\end{array}$ & $\frac{-}{1}$ & $\begin{array}{r}3 \\
2 \\
4 \\
-\end{array}$ \\
\hline Total & $\ldots$ & 26 & 16 & 1 & 9 \\
\hline
\end{tabular}

Table XIX shows that the prognosis was serious $N$ in this group of patients, for over one-third of $\underset{\mathrm{W}}{\mathrm{N}}$ them are now dead. On the other hand, every one of these patients who had an operation of planned extent with resulting cavity closure is now quiescent, except for two patients who had active $\stackrel{\mathcal{D}}{?}$ contralateral disease. Provided that the patient's respiratory reserve permits an extensive enough apicolysis and rib resection, these cavities can usually be closed. 
Cavities in the Contralateral Lung.-Table $\mathrm{XX}$ shows that the prognosis in these patients was poor, almost half being dead at the time of followup. Similar results have been reported by Seip (1949), Hagn-Meincke (1950), and Refsum (1951).

TABLE XX

CONTRALATERAL CAVITATION AND PROGNOSIS

\begin{tabular}{|c|c|c|c|c|}
\hline & \multirow{2}{*}{$\begin{array}{c}\text { Total } \\
\text { Patients }\end{array}$} & \multicolumn{3}{|c|}{ Present Status } \\
\hline & & Quiescent & Active & Dead \\
\hline $\begin{array}{c}\text { Definite cavity } \\
\text { present } \\
\text { Doubtful cavity } \\
\text { present } \quad \text {.. }\end{array}$ & $\begin{array}{r}16 \\
4\end{array}$ & $\begin{array}{l}7 \\
3\end{array}$ & $\begin{array}{c}1 \\
-\end{array}$ & $\begin{array}{l}8 \\
1\end{array}$ \\
\hline Total & 20 & 10 & 1 & 9 \\
\hline
\end{tabular}

The effect of thoracoplasty on cavities in the contralateral lung at the time of operation is far from clear, and references to this problem in the literature are scanty, though Price Thomas (1952b) states that contralateral cavities may close after thoracoplasty as a result of the relaxation afforded by correction of the mediastinal displacement. Most workers in the pre-chemotherapeutic era, however, took the view that where possible contralateral cavities should be closed by artificial pneumothorax treatment before proceeding to thoracoplasty. Even if this manœuvre were successful, it rendered the operation more hazardous (Abbey Smith, 1953) and the majority of the patients were finally left with very poor exercise tolerance. In the present series there were 16 patients with definite contralateral cavitation at the time of operation, in each case in the upper lobe. The cavity was certainly not favourably affected by the operation in 13 of these (cavity unchanged in size in 12 and larger in one, even though in the latter case the mediastinal displacement towards the operation side had been corrected). In two patients the contralateral cavities gradually closed during the six months after operation, but both had a contralateral artificial pneumothorax and one also had chemotherapy. In only one case did the contralateral cavity close spontaneously during the post-operative period and here bed rest may well have been responsible.

In this series there is no evidence that thoracoplasty had any significant beneficial effect on contralateral cavities.

IMPORTANCE OF FAMILY History OF PulmonaRY TUBERCULOSIS. - The work of Kallmann and Reisner (1943) and Puffer (1944) showed that there is a very important hereditary element in susceptibility to tuberculosis, but the question as to whether a hereditary resistance factor affects the prognosis of patients after surgery for pulmonary tuberculosis does not appear to have been studied previously.

TABLE XXI

FAMILY HISTORY OF PULMONARY TUBERCULOSIS AND PROGNOSIS

\begin{tabular}{|c|c|c|c|c|}
\hline \multirow{2}{*}{ Family History } & \multirow{2}{*}{$\begin{array}{c}\text { Total } \\
\text { Patients }\end{array}$} & \multicolumn{3}{|c|}{ Present Status } \\
\hline & & Quiescent & Active & Dead \\
\hline $\begin{array}{l}\text { History of fatal pul- } \\
\text { monary tuberculosis } \\
\text { in parent or sib } \\
\text { History of non-fatal } \\
\text { pulmonary tuberculo- } \\
\text { sis in parent or sib.. } \\
\text { Total patients with } \\
\text { family history of } \\
\text { pulmonary tuberculo- } \\
\text { sis... } \\
\text { No family history of } \\
\text { pulmonary tuberculo- } \\
\text { sis .. } \\
\text { No record of family } \\
\text { history . }\end{array}$ & $\begin{array}{r}142 \\
15\end{array}$ & $\begin{array}{l}59(87 \%) \\
119(84 \%) \\
11\end{array}$ & $\begin{array}{l}2 \\
3 \\
2\end{array}$ & $\begin{array}{l}7(10 \% \\
20(14 \%) \\
2\end{array}$ \\
\hline Total & 225 & $189(84 \%)$ & 7 & $29(13 \%)$ \\
\hline
\end{tabular}

Table XXI shows that in this series there was no significant difference in the late follow-up results of the two groups of patients with and without a family history of pulmonary tuberculosis. Furthermore, it was found that the two groups were almost exactly comparable as regards the extent of disease before operation. It seems probable, therefore, that a hereditary resistance factor does not significantly affect late prognosis in thoracoplasty patients.

EXTENT OF OPERATION.-An analysis of the late follow-up results did not reveal that operations of any particular extent gave better or worse results than the others. The significant point was not the extent of the operation, but whether or not sputum conversion and cavity closure had been obtained. It was not possible to study the efficacy of limited operations without embedding of the scapula, as only a few patients came into this category.

Presence of Other Diseases.-Patients who have chronic bronchitis and emphysema are poor operation risks. They tend to develop severe and irreversible bronchospasm immediately after operation and may die of cerebral anoxia. If they survive, they are likely to develop cor pulmonale. In this series all four patients who died of cor pulmonale had chronic bronchitis before operation.

Only three of the 231 patients were diabetics. One died of hypertensive heart failure, one still has active disease, and one is quiescent. Nowadays, 
the presence of diabetes should have little, if any, effect on the prognosis of a tuberculous patient.

Early Post-operative Results and ProgNosIs.-Each patient was assessed nine months after the last stage, and the disease status decided according to the criteria laid down above.

TABLE XXII

EARLY POST-OPERATIVE RESULTS AND LATE PROGNOSIS

\begin{tabular}{|c|c|c|c|c|}
\hline \multirow{2}{*}{$\begin{array}{c}\text { Disease Status } \\
9 \text { Months } \\
\text { after } \\
\text { Operation }\end{array}$} & \multirow{2}{*}{$\begin{array}{c}\text { Total } \\
\text { Patients }\end{array}$} & \multicolumn{3}{|c|}{ Present Status } \\
\hline & & Quiescent & Active & Dead \\
\hline $\begin{array}{ll}\text { Quiescent } & \ldots \\
\text { Active } & \ldots \\
\text { Dead } & \ldots\end{array}$ & $\begin{array}{c}195(87 \%) \\
24(11 \%) \\
6(2.7 \%)\end{array}$ & $\begin{array}{c}183(94 \%) \\
6(25 \%)\end{array}$ & $\begin{array}{c}7(3 \cdot 5 \%) \\
-\end{array}$ & $\begin{array}{c}5(2.6 \%) \\
18(75 \%) \\
6(100 \%)\end{array}$ \\
\hline Total & $225(100 \%)$ & $189(84 \%)$ & $7(3 \cdot 1 \%)$ & $29(13 \%)$ \\
\hline
\end{tabular}

From Table XXII it can be seen that $87 \%$ of the patients were quiescent nine months after the last stage, and in this group the eventual prognosis was excellent, only $2.6 \%$ dying during the follow-up period. The outlook for the 24 patients whose disease was still active at nine months was correspondingly bad ; three-quarters of them were dead at the end of the follow-up period. These 24 patients all had persistent cavitation. The cavity was on the operated side in 15 , on the contralateral side in five, and on both sides in four.

Nineteen patients remained with patent cavities on the operated side nine months after operation. The operation could not be completed in four of these (two inadequate respiratory reserve, one hysterical paralysis, and one tuberculous stenosis of lower lobe bronchus), and two had bronchopleural fistulae (one resulting from operative trauma, one from a pre-operative cavity rupture into a pneumothorax space). This leaves 13 cases where apparently technically satisfactory operations were not successful in closing cavities on the operation side. These are true "failed thoracoplasties." Nine patients were left who had cavitation in the upper lobe only, two with a cavity in the apical segment of the lower lobe, and two who had cavities in both these situations.

Length of Hospital Convalescence.-The importance of a long period of convalescence in treating pulmonary tuberculosis has often been stressed, but this view has been based on clinical impressions, for statistical proof is difficult to obtain, so many other factors being involved.

Clearly, patients whose disease was not rapidly controlled by the operation, who had complications, or whose progress was in any way unsatis- factory would often be kept in hospital longer than those whose post-operative course was uneventful. The former group of patients was therefore excluded from this part of the investigation, as they would weight the results in favour of the short convalescence cases. A few other patients were also excluded because full sanatorium reports were not available.

\section{TABLE XXIII}

LENGTH OF POST-OPERATIVE HOSPITAL CONVALESCENCE IN "UNCOMPLICATED" CASES AND PROGNOSIS

\begin{tabular}{|c|c|c|c|c|c|}
\hline \multirow{2}{*}{$\begin{array}{c}\text { Length of } \\
\text { Convalescence }\end{array}$} & \multirow{2}{*}{$\begin{array}{c}\text { Total } \\
\text { Patien:s }\end{array}$} & \multicolumn{3}{|c|}{ Present Status } & \multirow{2}{*}{$\begin{array}{c}\text { Patients } \\
\text { Relapsed } \\
\text { (Including } \\
\text { Deaths) }\end{array}$} \\
\hline & & Quiescent & Active & Dead & \\
\hline $\begin{array}{cc}\text { Less than } & 6 \\
\text { months } & \\
\begin{array}{c}\text { More than } \\
\text { months }\end{array} & 6 \\
& .\end{array}$ & $\begin{array}{l}85 \\
65\end{array}$ & $\begin{array}{l}79(93 \%) \\
61(94 \%)\end{array}$ & $\begin{array}{l}2 \\
3\end{array}$ & $\begin{array}{l}4 \\
1\end{array}$ & $\begin{array}{l}9(11 \%) \\
9(14 \%)\end{array}$ \\
\hline Total & 150 & $140(93 \%)$ & 5 & 5 & $18(12 \%)$ \\
\hline
\end{tabular}

In Table XXIII the number of " uncomplicated" patients who subsequently died is too small for analysis. The number of patients who relapsed is small, but there was no significant difference in the incidence in the short and long convalescenes groups.

It may be objected that the long convalescence group would contain a higher proportion of patients with extensive disease. On analysis, the two groups were found to be comparable in this respect, the long convalescence group actually containing a slightly higher proportion of favourable cases. This study affords no evidence that a long period of hospital convalescence improves the ultimate prognosis in patients who have had a successful thoracoplasty operation with no complicating factors.

This particular problem does not appear to have been investigated previously and the figures must be interpreted cautiously owing to the multiplicity of factors involved. It does seem probable that, especially where home conditions were good, the period of convalescence could often have been shortened with advantage.

\section{RELAPSES}

Twenty-nine, or $15 \%$ of 195 patients judged to be quiescent nine months after operation, relapsed o during the observation period of six to eight years. The late prognosis in these patients was reason-? ably good, only five having died.

Nineteen patients had a relapse in the contralateral lung. Of these, 15 were treated with 
TABLE XXIV

PROGNOSIS OF RELAPSED PATIENTS

\begin{tabular}{|c|c|c|c|c|}
\hline \multirow{2}{*}{ Site of Relapse } & \multirow{2}{*}{$\begin{array}{c}\text { Total } \\
\text { Patients }\end{array}$} & \multicolumn{3}{|c|}{ Present Status } \\
\hline & & Quiescent & Active & Dead \\
\hline $\begin{array}{l}\text { Operated lung } \\
\text { Contralateral lung } \\
\text { Both lungs } \\
\text { Unknown .. } \quad \ldots\end{array}$ & $\begin{array}{r}5 \\
19 \\
3 \\
2\end{array}$ & $\begin{array}{r}3 \\
12 \\
2 \\
-\end{array}$ & $\begin{array}{l}1 \\
3 \\
1 \\
2\end{array}$ & $\begin{array}{l}1 \\
4 \\
-\end{array}$ \\
\hline Total .. & 29 & 17 & 7 & 5 \\
\hline
\end{tabular}

chemotherapy alone; nine are now quiescent, three active, and three died of progressive disease. Two had artificial pneumothorax treatment and one contralateral thoracoplasty; these three patients are now quiescent. The remaining patient had a Monaldi drainage operation and died.

Five patients had a relapse in the operated lung. It is almost certain that in two of these patients the operation never closed the cavity, postoperative tomographs not having been obtained, and two more patients excavated previously solid lesions. Of this group of five patients three are now quiescent (two after chemotherapy, one after upper lobectomy), one is still active, and one developed a tuberculous empyema and died. In this series, reactivation of disease could only be attributed to "apical creep" in one case. This is in contrast to the findings of Holst (1952), who performed resections on 100 patients who had persistent cavities following thoracoplasty operations, and believed that re-expansion of the lung apex under the thoracoplasty was the crux of the problem. Meissner, Overholt, Wilson, and Walker (1949) concluded from a study of postthoracoplasty resection specimens that inadequate collapse as a result of a technically poor thoracoplasty operation was the outstanding cause of failure.

Although the lung apex sometimes re-expands, especially in patients with chronic bronchitis and emphysema, it is our opinion that this usually means that the apicolysis has been inadequately performed.

Three patients in this series relapsed with active bilateral disease. Of these, two are now quiescent following chemotherapy and one is still active.

These figures show that relapses are fairly common, and usually occur on the contralateral side. Seip (1949) reported similar findings. For this reason one should conserve as much lung function as possible at operation, in case surgery should later be required on the opposite side. Relapse on the operated side is uncommon in cases where the operation has been technically satisfactory.
Contralateral relapses appeared to be almost invariably due to reactivation of disease, rather than to bronchogenic spreads from active foci under the thoracoplasty, for they usually occurred in areas of old disease at the lung apex or subapex, in cases where the disease appeared to be controlled on the operation side.

TABLE XXV

TIME INTERVAL AFTER OPERATION BEFORE RELAPSES

\begin{tabular}{|c|c|}
\hline Years after Operation & Number of Relapses \\
\hline $\begin{array}{c}9 / 12-1^{*} \\
1-2 \\
2-3 \\
3-4 \\
4-5 \\
5-6 \\
6-7 \\
7-8\end{array}$ & $\begin{array}{l}2 \\
5 \\
7 \\
3 \\
3 \\
4 \\
3 \\
2 \\
2\end{array}$ \\
\hline Total & 29 \\
\hline
\end{tabular}

* Early assessment made at nine months after operation.

Table XXV shows that relapses continued to occur at a fairly steady rate until the end of the observation period, for it must be remembered that only a proportion of the patients were followed for longer than six years.

\section{SUMMARY}

Two hundred and thirty-one consecutive patients who submitted to thoracoplasty operations at the Arlesey Branch of the London Chest Hospital between December 1, 1947, and December 31, 1949, were studied, the follow-up period being six to eight years.

The case material was analysed in detail, this being essential if the results were to be of any significance.

Three patients $(1.3 \%)$ died within three months of operation and there were post-operative complications in $43(19 \%)$.

At the end of the observation period $82 \%$ of the patients were quiescent, $3 \%$ had active disease, $14 \%$ were dead, and $1.3 \%$ had been lost. Ninetysix per cent. of the survivors traced were fit for work. These results are considered to be satisfactory, for most of the patients had extensive disease and few received effective chemotherapy.

An analysis of the influence of various factors on late prognosis was made. Important factors were extent of disease, cavity size, pre-operative sputum state, and age, whereas the patients' sex, the presence of a family history of tuberculosis, and the length of hospital convalescence (in uncomplicated cases) did not appear to affect prognosis. 
Where operation resulted in sputum conversion and cavity closure the late prognosis was good, though $15 \%$ of these patients relapsed subsequently, usually on the contralateral side.

The material in this paper was used by one of us (J. H. G.) in a thesis accepted for the degree of M.D., University of Cambridge.

We wish to thank the medical superintendents of sanatoria and physicians to chest clinics, who were kind enough to send us reports about their patients.

\section{REFERENCES}

Adie, G. C., Childress, W. G., Brezing, H. J., and Taylor, D. (1952). J. thorac. Surg., 23, 92.

Baffes, T. G., Schlotterbeck, P., and De Camp, P. T. (1954). Ibid. 27, 349.

Beaconsfield, P., Coulthard, H.S., and Kergin, F. G. (1954). Thorax, $9,211$.

Dingley, H. B. (1950). Indian med. Gaz., 85, 14

Douglass, R., and Bosworth, E. B. (1954). Amer. Rev.Tuberc., 69, 930. Eley, A. J. (1956). Personal communication.

Forsee, J. H. (1954). The Surgery of Pulmonary Tuberculosis, p. 98 et seq. Lea and Febiger, Philadelphia.

Foster-Carter, A. F., Myers, M., Goddard, D. L. H., Young, F. H. and Benjamin, B. (1952). Brompton Hosp. Rep., $21,1$.

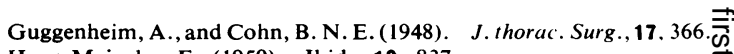

Hagn-Meincke, E. (1950). Ibid., 19, 837.

Holst, J. (1952). Nord. med., 48, 1288.

Hughes, F. A., Lowry, C. C., and Polk. J. W. (1953). J. thorac Surg., 25, 454.

Kallmann, F. J., and Reisner, D. (1943). Amer. Rev. Tuberc., 47, 549 $\frac{\text { (ه) }}{\text { A }}$

Laird, R. (1953). Lancet, 2, 319.

Lees, W. M., Yang, S. C. H., Papoulakos, M., Alexander, J., ande Larralde, A. (1951). J. thorac. Surg., 22, 329.

Meissner, W. A., Overholt, R. H., Wilson, N. J., and Walker. J. H $\overrightarrow{\vec{D}}$ (1949). Amer. Rev. Tuberc., 60, 406.

O'Brien, W. B., Wilson, N. J., Armada, O., and Vindzberg, W. $V:$ ज (1953). Ibid., 68, 874.

Ottosen, P., Popp, C., Beatty, A. J., and Buckingham, W. W. (1951) J. thorac. Surg., 21, 202.

Pines, A., and Rowlandson, R. (1956). Thorax, 11, 328.

Puffer, R.R.(1944). Familial Susceptibility to Tuberculosis. Harvard University Press, Cambridge, Mass.

Refsum, E. (1951). Acta tuberc. scand., Suppl. 29.

Report to the Medical Research Council (1951). Thorax, 6, 17. I

Rothstein, E., and Gilboy, J. T. (1952). Amer. Rev. Tuberc., 66, 2330

Seip, M. (1949). Acta tuberc. scand., Suppl. 19.

- (1953). Ibid., 28, 195.

Sellors, T. H. (1947). Thorax, 2, 216.

Smith, R. Abbey (1953). Ibid., 8, 106.

Thomas, C. Price (1952a). In Modern Practice in Tubercuiosis Vol. 2, p. 117. Edited by Sellors, T. H., and Livingstone, J. L Butterworth, London.

- (1952b). Ibid., Vol. 2, p. 137.

__ and Cleland, W. P. (1942). Brit. J. Tuberc., 36, 109. 